\title{
A violência insuspeita da sociedade de classes no trâmite da enunciação em Passageiro do fim do dia
}

Danieli Christovão Balbi ${ }^{1}$

\section{A crítica em questão}

A crítica que até então nos informa sobre Passageiro do fim do dia (2010) tem insistido em alguns elementos como chaves interpretativas para se chegar a um juízo a seu respeito. São eles: a caracterização da obra como um romance de memórias, pelo fato de os eventos narrados partirem, centralmente, das reflexões e observações do personagem principal; a concretude espacial que o livro explora como objeto de reflexão, porque esse espaço parece desafiar o protagonista Pedro; o diálogo produtivo com as referências ao naturalismo, presentes não só como dado da enunciação, mas produtivas também enquanto componente estrutural; e, através da articulação desses, a exploração da subjetividade dos personagens como efeito alcançado para bloqueio de uma leitura "determinista". Ainda que sob enfoques distintos, os críticos que até agora se debruçaram sobre a obra apostam nesses elementos como fundamentais à sua análise, relativizando e subordinando outros. De fato, alguns deles são tão flagrantes, que não se pode negligenciá-los quando da tentativa de apreensão do universo ficcional que Figueiredo nos entrega no romance em questão.

Larissa Paula Tirloni (2012), em "Memória e espaço em Passageiro do fim do dia", procura demonstrar como as referências ao tempo e ao espaço se despem de sua objetividade pela força da memória que as evoca, responsável por sua existência efetiva na malha do romance. Se é certo ser impossível dissociar a materialidade dos objetos que compõem o romance das memórias de Pedro, é verdade que essas memórias e associações, sendo ao protagonista ainda bastante obscuras, suas razões de ser insuspeitas, são produto de uma busca angustiante de ancoragem no real. Sendo esse um dado de composição estrutural, na medida em que o

\footnotetext{
${ }^{1}$ Doutoranda em ciência da literatura e professora Secretaria de Estado de Educação do Rio de Janeiro (Seduc), Rio de Janeiro, RJ, Brasil. (Dorcid.org/0000-0003-4899-0042. E-mail: natural.balbi@gmail.com
} 
romance se espraia do protagonista ao narrador e se modula a enunciação, cabe à sua análise elucidar esse dado.

Tirloni negligencia a separação entre narrador e protagonista, passando das considerações de um às memórias do outro de modo pouco detido e limitando aquele apenas a uma função organizativa, garantidora da estruturação do romance. A não linearidade do romance surgiria como prova do questionamento da importância da instância da enunciação, do distanciamento que ele pressupõe.

Para Santos e Fux (2013), em "A dramaticidade urbana de passageiro do fim do dia", a obra está centrada em uma representação do espaço cujo maior mérito é o justo entrelaçamento entre a fragmentação deste e as contradições dos que o habitam, irmanados pelas marcas que o espaço - aqui espaço urbano, a metrópole - lhes legou. De acordo com os estudiosos, no que eles consideram uma forma de romance de memórias, a cidade se converte em personagem que assume estatuto de protagonista. Isso pela riqueza descritiva que nele abunda e pela oferta incessante de imagens que compõem e caracterizam seu espaço. Entretanto, espaço urbano é, para eles, antes de tudo, simbólico, culturalmente marcado e subjetivamente delimitado, menos físico do que a sua configuração geográfica propriamente dita. Assim, o espaço pode ser também despido de sua objetividade, o lugar de onde Pedro observa e sobre o qual reflete, para além da cidade que atravessa. É a formalização de sua consciência íntima a partir de uma memória afetiva, exercida para autoconhecimento, o que faz de Passageiro do fim do dia (2010) um romance confessional, enunciado por um narrador de tipo "joyciano".

"Ler a cidade pela janela do ônibus", de Paulo Roberto Tonani do Patrocínio (2013a), identifica em Passageiro do fim do dia uma espécie de amálgama que rompe com a tradição de representação do espaço urbano por meio da moldura estática da janela ou do deslumbramento do transeunte. De acordo com Patrocínio, a cidade, para ser apreendida, necessita de algum meio que estabeleça, não definitivamente, essa apreensão, cujo resultado será sempre discurso. A cidade, pois, como espaço de múltiplos signos e disputa, só pode ser enunciada de forma provisória e a depender da ética particular que pavimenta essa enunciação. A impossibilidade de apreensão pelo dado, então, é voluntária em Pedro. O pesquisador, por fim, observa um dado importantíssimo: uma ironia do narrar que se funda na 
vacuidade da descrição pormenorizada, bem ao gosto naturalista. A ironia no trato do cientificismo darwinista, pois, para ele, serve puramente para pôr em xeque a pretensão à objetividade.

Em “Os (não) adaptados: a experiência urbana na obra de Rubens Figueiredo", Patrocínio (2013c) observa que, ao questionar o cientificismo darwinista, Figueiredo está, ao mesmo tempo, pondo em xeque a capacidade de apreensão do real pelos mesmos recursos que uma tradição naturalista mobilizou. Observa que o uso do naturalismo está a favor do questionamento de sua própria ética. Mas reclama para a obra o primado da subjetividade: para Patrocínio, a crítica ao naturalismo como discurso sobre a apreensão da realidade social soa como crítica a modelos totalizantes, o que acentua o caráter subjetivo das disputas e opressões a que assistimos.

Em sua dissertação de mestrado intitulada Gritos e ressonâncias do secreto: a poética narrativa de Rubens Figueiredo, Roberto de Andrade Lota (2013) observa um dado de composição extremamente importante de ser notado, caso se queira alcançar o estatuto da crítica pela articulação das referências dispersas na obra: o personagem cujas memórias e reflexões são a matéria do romance surge sempre mediado pelo narrador. Isso serve, imediatamente, para desdramatizar a intriga, possibilitando uma sorte de distanciamento que, mediatamente, induz a uma busca pela liga que a Pedro escapa, na sua condição de sujeito dessas profusões.

Lota também é feliz ao identificar que a situação limítrofe de classe, materializada na relação entre Pedro e Rosane, comparecem no romance à guisa de reflexão. Lota observa, ainda, com acerto, que a Pedro escapa o sentimento de comunidade e pertencimento que marca as relações interpessoais no Tirol, a par da violência do local.

Encerrando essa breve revisão crítica de Passageiro do fim do dia, retornamos a Patrocínio (2013b), por meio de seu artigo "Passageiro do fim do dia: um olhar sobre o naturalismo", em que o pesquisador procura, através da apreciação dos postulados do naturalismo, identificar os pontos de interseção e ruptura da obra em causa com o que parte da crítica especializada denomina de neonaturalismo. Identifica o autor, acertadamente, que a ruptura que faz com os padrões naturalistas e neonaturalistas, inscrita também na diegese, é, acima de tudo, estrutural. $O$ narrador em terceira pessoa parece submeter-se aos dados que emergem do olhar de Pedro, 
constantemente presentificado, mas segue, a partir disso, livre em sua refinada ironia, autonomizando-se nesse movimento. Patrocínio sugere uma obra cujo fôlego se deve à desestabilização do que considera a ética naturalista (planificadora) no seu centro de forças, por meio da mobilização de sua estrutura devida à articulação dos elementos narrador/protagonista/matéria narrada/estética naturalista. Aqui, então, Figueiredo propõe a deslegitimação perfeita da politização da arte (no sentido do que a arte tem a dizer de todos e a todos); do dado social que iguala os personagens, procurando pôr em relevo as disjunções que surgem por força das emergências subjetivas e desautorizam ver o homem como sujeito por suas relações sociais, sujeito de sua classe.

\section{Os movimentos conformadores de Passageiro do fim do dia}

A matéria de Passageiro do fim do dia formaliza uma viagem de ônibus realizada por Pedro, um homem de classe média, suas reflexões sobre a situação específica dessa viagem e suas divagações, estruturadas por um narrador em terceira pessoa que ora se aproxima ora se distancia desse personagem, movimento essencial para a configuração da obra. ${ }^{2}$ Os quadros existem a partir da observação, rememoração e reflexão de Pedro sobre a paisagem, a tensão da viagem, as personagens figurais que o acompanham, o livro que lê ou o sentido e efeito dos casos que viveu, observou ou lhe foram relatados por outros personagens que vão surgindo e, à medida que o romance avança, ressurgindo e se desenhando de forma mais ou menos complexa, pela apresentação destes em perspectiva e nuances que chegam para determinar a sua densidade e o grau de relevância que assumem na integridade forma-sentido de Passageiro do fim do dia.

A ordenação orquestrada pelo narrador deve ser tomada como norte exegético, uma vez que, ao surgirem a partir das associações em certa medida espontâneas e fragmentadas de Pedro, que os realiza, a dispersão dessas associações e seu caráter a princípio esparso vão, com

\footnotetext{
${ }^{2}$ A perspectiva de classe que a leitura sugere está baseada na divisão social da produção e do trabalho, como apontam Karl Marx, e Friedrich Engels (2011) em O manifesto comunista, de forma sintética e seus matizes superestruturais correlacionados e de apreensão complexa, levantados em A ideologia alemã (2001).
} 
aparente casualidade, configurando-se dentro de blocos que a perspicácia narrativa sugere. Algumas questões com que se debate Pedro inscrevem-se como unidades temáticas da obra, em cadeia, entrelaçadas por associação. Nesse ritmo, uma série dessas unidades temáticas é articulada, de modo intermitente, cujos referentes mais importantes são o universo e as relações de trabalho, a forma mercadoria, o estabelecimento de identidade e solidariedade, a promoção ou recalque da violência, o determinismo naturalista.

Pedro, Rosane e Júlio indicam, de algum modo, o fluxo das alternativas à disposição dos indivíduos que pertencem à mesma classe que eles. Em sua relação entre si e com o mundo, esses personagens concretizam, de certa forma, um vetor que, às vezes, ainda que apenas superficialmente, vai na contramão do que lhes é dado. Â clarificação da integridade da obra é crucial que se perceba o exato alcance dessas trajetórias e o que isso determina.

Pedro é insistentemente descrito ao longo do romance como alguém distraído, disperso, que, por mais que se esforce em se concentrar, tem grandes dificuldades, o que é pelo próprio personagem reconhecido, motivo de angústia e objeto de suas reflexões. As coisas que se lhe afiguram escapam a ele, como se tudo, faceiramente, quisesse se ocultar:

Não ver, não entender e até não sentir [...] um distraído, de certo modo - e até meio sem querer [...] ali estava uma qualidade que, quase aos trinta anos, já podia confundir com o que era - aos olhos das pessoas. Só que não bastava. Por mais distraído que fosse, ainda era preciso buscar distrações (Figueiredo, 2010, p. 7).

À medida que o romance caminha, vemos que essa característica do personagem aparece muitas vezes de modo peculiar e intrigante: Pedro, na verdade, até se atém demasiadamente aos objetos que surgem, aos dados que aparecem, mas, quanto mais neles se detém, mais seus sentidos escapam. "Buscar distrações" tem um sentido irônico que acentua esse movimento repetido e irrefletido. Pedro observa, perscruta, escrutina, mas não chega a nada. Busca ater-se e apreender, mas seu esforço tem o mesmo efeito de uma distração. $\mathrm{O}$ protagonista, então, de saída, é traçado como alguém incapaz de ultrapassar, ainda que provisoriamente, a superfície das coisas; Pedro é a síntese entre distração e atenção que configura a 
inapreensão. Mesmo as conclusões a que chega são provisórias, apresentadas em forma de questionamento, que as relativizam para desfazê-las. Essa inapreensão, posto que Pedro exerce a função de polo irradiador da matéria do romance, marca seus quadros e lhes confere, em sua natureza de fenômeno, um caráter oculto que leva a questionamento e desperta interesse na captação do seu sentido insinuado; um sentido que está constantemente à espreita.

De saída, o protagonista percebe que está deslocado do universo de relações que abre o romance, que não há alguma forma de identidade com seus companheiros imediatos. Depois de analisá-los e até conhecer alguns de seus hábitos, como que por osmose, conclui: "Mesmo assim, mesmo próximo, estava bastante claro que não podia ver as pessoas na fila como seres propriamente iguais a ele. A razão, Pedro ignorava" (Figueiredo, 2010, p. 9). Em que medida ignorava? Era como se Pedro pressentisse uma hostilidade por parte deles, latente, não manifesta, mas concreta, sem da qual sequer arriscava o motivo: "Por que eles permitem que eu fique aqui? Por que não me expulsam, como é de seu direito?" (Figueiredo, 2010, p. 10). Mais adiante, o narrador observa, distanciadamente, em discurso indireto, que

[...] sua atenção tinha mais força do que qualidade. Enxergava bem, mas olhava como que de longe, ou como que através de um furo na parede. Sem ser visto, Pedro não se via. Não conseguia imaginar que aspectos teria - as costas, os braços, a nuca - aos olhos daquelas pessoas (Figueiredo, 2010, p. 11).

Interessante assinalar que essa inferência é encaminhada pelo narrador como conclusão de um corte na estruturação da enunciação que, até pouco, vinha sendo construída em discurso indireto livre - o corte constitui recurso extremamente produtivo no romance em causa -, cuja força apontava a dispersão de Pedro em sua análise do que o circundava, sem que, no entanto, houvesse qualquer possibilidade de conclusões definitivas, somente questionamentos reincidentes. Mais interessante se torna o fragmento destacado se nos atemos ao fato de que, mesmo que haja um corte na narrativa, um paulatino distanciamento entre as instâncias do enunciado (Pedro) e da enunciação (narrador), por força da autonomia desta em relação ao protagonista, o que exatamente se oculta não nos é esclarecido de pronto. Por exemplo, a corporeidade de Pedro que surge no trecho destacado como metonímia é uma sutil indicação do narrador de que 
devemos lê-la como metáfora. Mas do que? Que sentido há em Pedro não ser visto e, na mesma medida, não enxergar a si?

$\mathrm{O}$ corte do indireto livre para o indireto e o fato de isso, em si, sugerir mais do que esclarecer configuram uma forma de provocação recorrente na obra. Somos levados a percorrê-la porque não temos a resposta por Pedro, nem o narrador já distanciado do personagem a entrega a nós, apenas nos indica que ela está lá, paira em sua atmosfera, e nos instiga a uma leitura em sua busca. Como encontrála? No caso específico, os eventos narrados em seguida informam uma distinção entre Pedro e seus companheiros de fila do ônibus: a natureza do trabalho que executam é diferente:

Como os outros, estava cansado, não tinha carregado caixotes de frango congelados para a caçamba de um caminhão nem havia esfregado corredores e escadas de um prédio de quinze andares de cima até embaixo como alguns ali, mas tinha ficado muito tempo em pé no trabalho (Figueiredo, 2010, p. 11).

Essa informação aparece breve e circunstancialmente inserida no texto. Ela faz parte do que Pedro reconhece, mas ao que não se atém, ao menos aqui, onde ela interessa. É apenas um caminho para a constatação do cansaço que compartilha com os demais, o que obscurece a distinção mesmo de conteúdo, que não se desenvolve. Logo em seguida, Pedro ressurge em suas dispersões.

Essa estruturação se repete ao longo do romance. Como dito, a passagem do indireto livre ao indireto e vice-versa é recorrente, é a forma produtiva da obra. Nestas formas há a presença ou indicação maliciosa de algo que se oculta, mas não se esclarece no enunciado. É apenas por meio da análise da montagem que se pode arriscar alguma resposta. Não foi Pedro quem percebeu, nem o narrador quem nos disse, ainda que tenha sugerido. Mas, se o leitor se deixa inquietar pela certeza ardilosamente orquestrada de que algo está oculto, sua atenção redobra-se e já não pode mais entregar-se à leitura inadvertidamente. Percebendo, pois, o livro como arranjo, como montagem, sua integridade se esclarece, já que, em algum lugar desse movimento modular da enunciação alguma informação entre seus quadros esclarecerá o que procuramos.

É o que ocorre na passagem acima, quando, entre as elucubrações de Pedro, sua formalização pelo narrador e as considerações deste sobre elas, observamos um único dado objetivo, não destacado, 
quase despretensioso em sua secura circunstancial, seguro, todavia, do que de fato se oculta à questão inicial que abre a narrativa; o que, concretamente, distingue Pedro dos demais: o trabalho que realizam. Assim ocorre com outras questões com que se debate Pedro, que se inscrevem como unidades temáticas da obra, em cadeia, entrelaçadas por associação. Nesse ritmo, uma série dessas unidades temáticas é articulada, de modo intermitente, cujos referentes mais importantes são o universo e as relações de trabalho, a forma mercadoria, o estabelecimento de solidariedade, a promoção ou recalque da violência, o determinismo naturalista.

O quadro que dá conta do início do relacionamento de Pedro e Rosane nos mostra as relações de trabalho do casal de protagonistas e seu amigo Júlio, indicando que posições os três ocupam, iluminandoos a partir disso. $\mathrm{O}$ enunciado que nos revela que Pedro, um jovem de classe média carioca, havia abandonado o curso de direito de uma universidade pública após seis anos de sucessivos "fracassos" que marcaram sua trajetória acadêmica forma uma oração adverbial temporal. Bem diluído na malha discursiva, sua função é servir como operador entre o leitmotiv do acidente de Pedro e a passagem que relata o início de seu relacionamento com Rosane. Essa oração encerra um breve e objetivo parágrafo que descreve a mãe de Pedro de forma sucinta, cujo enfoque recai sobre sua situação de mulher de classe média, seus anseios e expectativas bastante prototípicos. A partir daí, temos uma passagem que, introduzindo a formação do casal, apresenta as dificuldades de Pedro com o curso de direito e sua amizade com Júlio, os caminhos seguidos pelos amigos e a condição de classe de Rosane. Quando chegamos, enfim, à aproximação do casal, já possuímos algumas informações relevantes que estão sutil e maliciosamente dispersas entre diversas modulações da enunciação que constrói a narrativa (Figueiredo, 2010, p. 43-45).

Além da configuração de classe a que pertence a família de Pedro, sabemos, por exemplo, que Júlio, diferentemente do amigo, tendo sido aluno bastante aplicado, estava plenamente identificado ao universo de trabalho, em que se inseriu com auxílio de parentes e que é, mais ainda, bastante animado pela possibilidade de ascensão social que ele lhe proporciona. Pedro, ao contrário, aparece indiferente às vantagens acenadas pela carreira, consumidor modesto e nada deslumbrado. Conhecemos a medida da situação do trabalho subalterno não 
especializado de Rosane e travamos o primeiro contato com sua atenção e perspicácia, um traço característico que algumas vezes serve para pô-la em oposição a Pedro.

Não é por acaso que esse quadro, composto de tantas cenas, produto de associações de memória dispersa e configurado inteiramente por modulações narrativas, tem como espaço fundamental um ambiente em que se desenrolam essencialmente relações de trabalho. Isso marca a importância que elas assumem na construção de sentido do texto. A perscrutação do arrolamento exato entre os segmentos estruturais que o formam logra esclarecer muitos aspectos do romance. Em primeiro lugar, já sabemos que Pedro é disperso e desatento, e esse é apresentado como um dos motivos que o levaram a abandonar a faculdade de direito. Se articularmos esse dado ao valor que Rosane, ao se dar conta de que Pedro é o primeiro homem de classe média com quem saiu, fechando o quadro, atribui à faculdade de direito pública, conseguiremos entender um pouco mais do sentido de sua dispersão, na forma como ela surge agora. A universidade pública foi, por muitos anos, como sabemos, um patrimônio a serviço da elite brasileira, cujo acesso garantia à classe média ser ali adestrada e poder, talvez, chegar à mobilidade social, seja pelas relações de trabalho que ela projeta, seja pelas relações sociais peculiares. $\mathrm{O}$ descuido de Pedro com o curso de direito toma a forma de desinteresse pelo que ele pode proporcionar. Talvez até Pedro não percebesse tão claramente o que significava nesse sentido o curso, mas seu descaso por ele, se relacionado à sua forma de trabalho e às escolhas moderadas em relação ao consumo, contornam um desdém pela escalada social como caminho perseguido pelo jovem de classe média brasileira, de que Júlio é representação. Essa inferência não pode parecer descolada de outras, por ter força para encaminhar uma identificação a partir de uma valoração de Pedro, o que o romance não faz. A essa altura, já sabemos que Pedro possui um pequeno negócio de livros usados. Logo, sua posição na cadeia produtiva e a natureza de seu trabalho, se não lhe proporcionam acúmulo de capital, são, por essa razão, bem diferentes das de Rosane, o que Pedro só percebe muito tempo depois de iniciarem o relacionamento, não sem surpresa. Além disso, nada no romance nos autoriza a concluir que Pedro se desinteressa pela escalada social por escrúpulos. Pedro não faz nenhum grande esforço, aliás, e isso é bem 
marcado ao longo da narrativa. Atando todas essas informações, pode-se afirmar que a desatenção flagrante de Pedro é também, como ela figura no quadro em questão, alienação, no sentido lato do termo, em que exprime desconhecimento e mesmo desinteresse pela estrutura social (nesse caso, sociedade de classes) em que se insere.

No quadro em questão, cujo objetivo central parece ser mostrar o início de um relacionamento amoroso, os três personagens surgem no jogo de classes que mobilizam. A alienação de Pedro o impede de entregar inferências sobre isso, apenas permite associações dispersas que fragmentam informações cuja perscrutação da montagem desses dados na estrutura do romance é crucial para acessarmos seus sentidos. O parágrafo deste quadro é revelador:

Só por um instante, com surpresa, sentiu-se ligeiramente culpado diante de Rosane. Talvez por não saber tanto inglês quanto devia, talvez por não saber de quantos por cento era o desconto e haver nisso certo descaso pelos esforços da mãe. E assim achou também que sua culpa era em relação à mãe, de quem, por um momento, naquela situação, se lembrou meio constrangido (Figueiredo, 2010, p. 48).

Pedro sente as fragilidades de Rosane e algum remorso de classe, mas não os compreende. O sentimento de culpa, ainda que decorrente da percepção da assimetria social que os distinguia e que possa significar algum aclaramento da questão de classe que os distancia, não chega a realizar o esclarecimento de sua situação de classe específica.

O romance é repleto de passagens que descrevem com minúcias diversas formas mercadoria e diferentes dinâmicas que levam à sua posse, o que assinala uma obsessão narrativa. Nesse mesmo quadro, as roupas que vestem os personagens funcionam como um signo de distinção importante entre os três. As referências a essa distinção levam à consideração sobre o modo como eles participam do universo do consumo e, por conseguinte, de que maneira a forma mercadoria atua como agente de ordenação da sociedade de classes, o que indicia o sentido de sua recorrência na obra.

Júlio tinha uma cara grande, risonha, redonda, uma expressão amistosa em que não se percebia quase nenhum ângulo de osso. O tronco encorpado, largo, recheava com fartura os ternos que ele passou a vestir todos os dias, com muita naturalidade, assim que se formou e começou a trabalhar na 
firma de advocacia [...]. Pedro não tinha ternos. Por economia, só vestia roupas compradas na calçada, em feirinhas de rua e camelôs. Eram sinais que Rosane logo identificava e entendia prontamente. Na verdade, quase tudo, tanto os objetos quanto as pessoas, se traduziam nos termos desse idioma - quem comprava o que e por quanto. E Rosane nem tentava imaginar como seria possível viver fora dele (Figueiredo, 2010, p. 45).

A caracterização de Júlio também insiste em encaminhá-lo com antítese de Pedro. Os dados que respondem sobre a compleição física daquele não são aqui relevantes à comparação entre eles, tanto que o Pedro não é encerrado por traços dessa natureza. Mais adiante, os poucos dados de descrição física que encontramos são referentes à Rosane, os quais acentuam sua magreza: "E a partir dos dentes Pedro se deteve nos ossos compridos de Rosane e em como ela era toda magra" (Figueiredo, 2010, p. 47). Essa característica de Rosane será, muitas vezes ao longo da obra, objeto de atenção e reflexão por parte de Pedro. Antes disso, ele havia acabado de notar que Rosane era a mulher mais pobre com quem já havia saído, e percebido, acertadamente, o como isso a deixava vulnerável. Logo em seguida, Rosane percebe também que Pedro é o homem mais abastado com quem já se relacionara e, nesse momento, traz de relance à memória a amizade incomum de seu namorado com Júlio, em que o advogado é lembrado, de passagem, como um homem na iminência de ganhar muito dinheiro.

Por que a descrição física de Júlio comparece se não há comparação da mesma natureza com Pedro? Será que a referência à magreza de Rosane é gratuita? E a referência ao previsível enriquecimento de Júlio nas memórias de Rosane? Tudo isso reforça a posição desses personagens em suas relações de trabalho, acúmulo e consumo. Não parece ser gratuito o fato de Pedro estar colocado entre Rosane e Júlio, sem que um dado de seu físico seja mencionado. Isso acende a contradição entre Júlio e Rosane. Se ele é robusto e encorpado, ela é toda magra. A menção à estrutura óssea da moça, metonímia de sua fraqueza que ressurge sempre a Pedro na narrativa, aqui acentua sua figura de alguém que não retém, alguém que não pode acumular, metáfora de sua expropriação pela forma de alienação de seu trabalho, também apresentada no mesmo quadro. Ao contrário de Júlio, cada vez mais senhor de capital e quase irmanado ao patrão - dono do 
produto daquilo que expropria de Rosane -, ela não pode se dar ao luxo de participar com tranquilidade do universo do consumo, talvez como até quisesse, e é incapaz de viver de outro jeito a não ser considerando a moderação, que se torna concreta pela redução de possibilidades, sempre tendo em conta que as relações se resumem, por fim, a quem compra o que e o valor dessa transação.

Desse modo, é diferente também de Pedro, na medida em que sua moderação não advém de uma necessidade tão concreta. Tanto que a escolha por um motel barato, menção à maneira como ele atua diante do imperativo de consumo, é feita por Pedro mais por conveniência do que por necessidade. Pedro se surpreende, como fica claro mais adiante, com a forma de urgência e necessidade que a relação de Rosane com a mercadoria adquire. Observa, com certo interesse, por exemplo, como ela, dentro do supermercado, assume aspecto compenetrado, como se estivesse em disputa:

$\mathrm{Na}$ verdade, os produtos distraíam Pedro em sua profusão de nomes, feição utilidade. Uma espécie de desfile, de exposição (talvez porque em sua casa não era ele, em geral, que ia ao supermercado e fazia as compras, mas sim a mãe). Já Rosane se guiava orientada por um olhar atento, rigoroso, quase enciumado dos seus objetivos e resultados. Era visível que ela mobilizava os conhecimentos adquiridos em muitas idas ao supermercado, em muitas ocasiões e compra. Acreditava distinguir vantagens, descobrir oportunidades onde Pedro só enxergava apenas um tumulto indiferente (Figueiredo, 2010, p. 96).

Não são opções de consumo que os distinguem, mas os imperativos que os levam a elas e a forma como se percebem inseridos em seu universo, o sentido que atribuem à forma mercadoria e o que determina suas atuações. Pedro pode distrair-se e dar-se ao "modesto luxo" de não se responsabilizar por seu sustento, a cargo de sua mãe. Sua relação com a mercadoria não assume, por fim, a tragicidade da sobrevivência. É isso o que, a rigor, constitui diferença de fundo entre ele e sua namorada. Essa tragicidade e a fetichização que se concretizam na perspicácia de Rosane, no terno de Júlio e na economia de Pedro, em suma, está em diversas outras passagens em que a obsessão descritiva pela mercadoria se atualiza, o que é elaborado para evidenciar sua força como agenciador de desigualdades inerentes à divisão do trabalho na sociedade de classes. 
Rosane está, a princípio, identificada com seus pares, e mesmo quando se percebe diferente deles, não chega a se distanciar. Essa identidade se manifesta muitas vezes no romance, e tematiza uma solidariedade que a Pedro inquieta, reconhecendo-se, no limite, como impedido de manifestar essa empatia com os companheiros da viagem e moradores do Tirol.

Por exemplo: não era raro Pedro se distrair, se esquecer, não notar. Mas de repente se impressionava ao ver como mais uma vez Rosane não conseguia ficar indiferente a quase ninguém no Tirol. Ela perguntava, conversava, queria saber a respeito das pessoas. Pedro via com clareza que o interesse de Rosane não era consciente, ela nem pensava no que estava fazendo [...]. Bastava ela repetir meia palavra que o outro tinha dito, bastava respirar no mesmo compasso, bastava olhar em silêncio na mesma direção que o outro, deixar que o olhar se demorasse por mais tempo que o necessário para enxergar o que estivesse lá - bastava uma sintonia que Pedro sentia, com toda certeza, impossível para ele imitar (Figueiredo, 2010, p. 180).

$\mathrm{Na}$ viagem que realiza do centro ao Tirol, Pedro está acompanhado de um rádio de pilha e um livro que trata da viagem de Charles Darwin ao Brasil, quando teria explorado a mesma região em que hoje se ergue o bairro de destino. Já sabemos que muitas reflexões e associações que ele faz são decorrentes de considerações a respeito da obra e do teor do naturalismo, em muitas ocorrências de forma bastante variada. São também abundantes no romance as descrições que aludem ao método de análise encaminhado por Darwin. Como recurso narrativo, o cientificismo darwiniano está presente na abordagem da matéria da obra, como elemento do enunciado, em que abundam descrições distanciadas de objetos e objetificação de fatos para se seguir à sua apreensão. Esse é, como bem sabido, um dos expedientes da estética naturalista, cuja ética inerente pressupõe dissecação e distanciamento, rigor fotográfico e ausência de subjetividade. A organização dessa referência na obra participa, na verdade, como elemento de composição de modo bastante refinado. Analisando as singularidades do trecho abaixo destacado, a despeito de outros em que as referências aparecem mais diretamente, seu sentido se clarifica. 
Pensando bem, não era tanto uma questão de hábito, nem de mimos. Acontece que toda hora é hora de avançar na escala evolutiva, subir mais um degrau, é mesmo impossível ficar parado e, qualquer que seja a direção em que as pernas começam a andar, o chão logo toma a forma de uma escada. Além do mais, é preciso reconhecer: sem mal-estar, sem adversidade, sem um castigo sequer, como se pode esperar que haja adaptação? (Figueiredo, 2010, p. 8).

As referências à obra e aos estudos de Darwin só aparecem no romance mais adiante, porém, nele estão dois elementos lexicais que, diretamente, fazem alusão a conceitos naturalistas: "escala evolutiva" e "adaptação". Esse trecho, inserido bem no início do romance, configura uma conclusão a respeito de observações sobre a hostilidade do lugar em que está o protagonista, metonímia da brutalidade do caos urbano.

De saída, um tom irônico inaugura o corte entre a observação e a conclusão, na qual que se observa a presença de uma série de elementos que encaminham uma sorte de depreciação: a presença de marcas de oralidade, como as estruturas "acontece que" e "além do mais"; a reflexão em indagação direta; a conclusão por silogismo, cuja forma parece indicar que uma das premissas é baseada em doxa, no senso comum. Trata-se, sem dúvida, de discurso indireto livre. De quem, na verdade, toma o narrador essa liberdade? Se considerarmos que é de Pedro, como a estrutura insinua, temos de supor que os juízos de Pedro devem tomar sempre essa configuração ao longo do romance. No entanto, as reflexões posteriores de Pedro, a partir daqui, terminam sempre em dúvidas, cujo tom nem mesmo se aproxima das certezas colocadas no trecho em questão. Inclusive, quanto mais Pedro trava conhecimento da obra que lê, menos seguro se torna e menos esclarecido se mostra.

Talvez seja possível inferir que o Pedro que se debate com Darwin começa desde já uma desestabilização, porque, ao contrário do esperado, o livro lhe incute mais dúvidas do que certezas. Seja como for, o trecho dialoga com uma espécie de lugar comum que, claro está, se relaciona à teoria Darwiniana. E qual elemento do senso comum está sendo posto em questão pelo procedimento narrativo aqui adotado? Pelo teor do que é mobilizado, poderíamos dizer que se trata mesmo da matéria do enunciado: a brutalidade das relações 
e a lei da evolução. A todo momento vemos que a teoria falha, seja pelas suas contradições internas, seja pela nulidade descritiva de muitos quadros, também um procedimento narrativo interessante: $\mathrm{o}$ narrador distancia-se do personagem e, após apreender as formas da superfície de algo, não chega a nenhuma conclusão significativa.

Ao longo de todo o romance, a dispersão de Pedro também comparece na forma de atenção que disseca uma série de objetos e seus aspectos, os quais nada dizem a respeito do que ele de fato procura. Todavia, algo permanece, e é justamente a evidência da brutalidade, da animosidade e a ingrata corrida pela sobrevivência. Bem assim, a narrativa não descredibiliza simplesmente a observação do fato, o dado superficial, mas nos adverte que ela por si só nada esclarece; a constatação de que as coisas existem no grau de perversidade em que se apresentam não deve ser tomada, no limite, como evidência da perversidade inscrita nelas mesmas. Ou seja: não se deve naturalizar o que se observa, somente porque acontece. Não é, portanto, a observação e conclusão da perversidade o que se condena - uma vez que insistente, trata-se de obviedade -, mas sua naturalização, e a ironia do trecho citado anteriormente então se esclarece como crítica ao determinismo ingênuo e paralisante, à aceitação passiva e descuidada do que se observa na ordem das coisas e serve para legitimá-la. É essa naturalização, em suma, que está presente na modulação enunciativa do discurso indireto livre como objeto de depreciação, pela fineza da ironia. Esse é o sentido da referência ao naturalismo.

As imagens de brutalidade se relacionam de modo sugestivo com o tema da violência, mas não chegam a ancorar sua abordagem, sobre o que o romance se detém. A estratégia de inserção desse tema é o que atribui significação a ele. Curioso perceber que, se abundam imagens que procuram desnudar a barbaridade cotidiana na forma como a experienciamos e pressentimos, na sua relação insuspeita com o universo do trabalho, o sentido de comunidade e o senso comum que sanciona a selvajaria como competição, a violência etc., a luta de fato está na iminência de ocorrer, manifesta-se por sugestão e paira na atmosfera da obra sem que chegue a se concretizar no plano do presente de Pedro. Aparece como reminiscência e representação, e é somente desta forma que podemos encerrá-la no romance. A passagem a seguir configura uma representação da violência esclarecedora: 
Queixo erguido, o juiz olhou para a porta - para a rua. Pedro olhou também. Lá fora, os dois meninos com camisetas imundas que chegavam aos joelhos atravessaram de uma calçada para a outra. Descalços, passos vagarosos, não pareciam sentir o calor do calçamento de paralelepípedos, que rebrilhava cor de prata ensolarado. Os dois vieram para a porta da livraria sem dar a menor atenção ao olhar fixo e à cara francamente hostil do segurança de paletó e gravata [...]. Pedro sabia aonde iam os dois meninos. Dariam uns poucos passos à esquerda $\mathrm{e}$ iriam parar na porta da loja de internet, vizinha à livraria. [...] E os dois acompanhavam os lances como se também jogassem, como se fossem eles também os desenhos as figuras, as formas de vida que na tela corriam e pulavam - como se fossem também deles os olhos, o olhar cuja visão o jogo representava, numa imagem que tomava a tela toda [...]. Às vezes Pedro ia ali para ver se havia mensagens ou pedidos de livros para ele no computador [...]. Por isso tinha visto, um dia, de manhã, dois meninos de uns dez anos, no máximo, em uniformes de escola, sentados em cadeiras de plástico branco, diante do computador. Um deles jogava com só um fone no ouvido - a orelha direita livre. O outro o acompanhava de pé ao seu lado, curvado para frente: dava instruções, incentivava repreendia [...] em seguida, Pedro se deu conta do que o cenário representava - a maior parte era ocupada por asfalto - ele notou desde o primeiro relance, havia algo muito familiar naquela superfície plana [...]. Mas não eram ruas, como Pedro supôs, nem avenidas nem mesmo estradas na zona rural. Os garotos descalços, sujos e abraçados a garrafinhas com solvente, não chegavam aos computadores, não jogavam - pelo menos Pedro nunca tinha visto. Mas eram aqueles jogos que eles queriam acompanhar, nem que fosse ali da porta mesmo, meio de longe, encolhidos contra a parede, os olhos acesos, os pescoços esticados para o lado de dentro, um pé apoiado no degrau de uma entrada, o outro para o lado de fora (Figueiredo, 2010, p. 132-143).

Os fragmentos acima fazem parte de um quadro que começa a se configurar na página 122 e só se pode dar como encerrado na página 145. Nele há tantas referências articuladas, que poderíamos propô-lo, 
sem exageros, como núcleo condensado do romance. ${ }^{3}$ Começa narrando o encontro de um juiz, chefe de Júlio, com uma ex-aluna sua e agora também juíza, ocorrido na seção especializada de direito que ambos costumavam frequentar na livraria de Pedro. Não por acaso, ficamos sabendo, aqui, que fora esse juiz quem reacendera o interesse de Pedro pelo livro sobre Darwin. Tomamos conhecimento da sua figura impertinente através das rememorações do relato de suas relações familiares e de vida perdulária cujos dados eram trazidos por Júlio a Pedro, de quem o juiz é chefe e mentor. Entre o juiz e sua exaluna há um tom de cumplicidade e tolerância. Conversam sobre o sistema prisional brasileiro e as situações dos que o compõem, sobre o que o vaticínio do juiz é apocalíptico: "mais dia, menos dia, eles vão dar cabo de todos nós" (Figueiredo, 2010, p. 126). Os magistrados, então, discorrem sobre as reformas do sistema jurídico, desde seus instrumentos burocráticos, como o uso do computador, à inclusão de penas alternativas, o que demarca a posição mais progressista da juíza diante do conservadorismo niilista de seu colega. Surge diante de nós a imagem do jogo de videogame, fruto das associações de Pedro perante os menores acima descritos. Só depois de acompanhar as pirotecnias de que o jogo se vale, Pedro percebe que o seu objetivo se resume a matar o maior número de policiais possível.

$\mathrm{Na}$ apreciação da violência, muito se camufla, a começar pelo próprio interesse por ela despertado, que não se sabe a partir de que elementos surge. Aqui se insinua um inquietante questionamento: o que há em comum entre eles que os leva a se deixarem assimilar pelas imagens ali construídas, sendo referentes da rigidez da estratificação de classes, de forma tão bem marcada na cena em causa através, inclusive, do uso da perspectiva das portas de vidro no cenário como metonímia dessa estratificação?

A discussão sobre a informatização do sistema jurídico é travada como algo central, o que torna a denúncia patética, porque mostra a perspectiva cerrada sob a qual tecem considerações generalizantes. Logo a narração do jogo a que assistira Pedro começa. Nela se sobressaem dois aspectos do jogo que são reincidentes: a constante reanimação de seus planos, impressa no fôlego da narrativa, que

\footnotetext{
${ }^{3}$ É onde melhor observamos a visão holística da sociedade de classes que Figueiredo empreende, com referência não só ao consumo, universo do trabalho e violência, mas também à configuração dos relacionamentos afetivos nessa sociedade, ao espaço que a mulher nela ocupa etc.
} 
chega a ser conduzida no tempo presente; e as referências às palavras em inglês e japonês, que surgem em dado momento do game, além da profusão de símbolos alfanuméricos, todos para informar comandos precisos. Não é preciso ir longe para inferir a crítica à globalização e seus agentes dominadores (os Estados Unidos, principalmente) que, por conseguinte, atualiza a crítica à padronização que estes signos operam. A violência, então, é um padrão de atuação social, regida de forma muito sutil e incutida sorrateiramente por uma profusão de passadas, pela provocação da excitação através de ritmo alucinante que, enquanto recurso imagético, não permite sequer sua consideração mais profunda, mas anima os homens ali envolvidos. Surge um aspecto da naturalização da dominação, da ordem predatória que mantém o estado das coisas e deve ser despercebida, apenas assimilada. O desenvolvimento tecnológico, referenciado por aparelhos do universo da cultura de massa, sobretudo os que se valem da exploração da imagem (o computador, o cinema, a televisão) são agenciadores do processo de alienação a que não escapa ninguém:

Mas logo depois dispararam na tela os passos de um homem de terno elegante como uma enorme pistola prateada na mão. Ele corria com ímpeto pelo meio de uma rua larga, no meio dos carros que passavam bem perto e buzinava. $\mathrm{O}$ homem dava tiros para trás, sem parar de correr e quase sem fazer pontaria: voltava a arma sobre o ombro e puxava o gatilho. Entre um tiro e outro, gritava nomes próprios ingleses, que mesmo gritados soaram baixinho na sala nomes que amigas e conhecidas de Rosane escolhiam para dar aos filhos (Figueiredo, 2010, p. 55).

E mais adiante:

O pai de Rosane contava para Pedro, falava um bocado e parava, quando alguma coisa na televisão prendia seu interesse. Era um filme americano, havia filmes de vez em quando, armas de vários tipos - em gavetas, em cintos, em bolsas, no porta-luvas, em mãos de homens e mulheres, os canos cromados ou pretos rebrilhavam na tela. Homens voavam para trás, de braços abertos, com manchas vermelhas no peito da camisa, o corpo rolava sobre o capô brilhante dos carros novos ao som de explosões e de música 
trepidante. Ora um casal se beijava com força, os dedos esticados da mulher, de unhas compridas, enterravam-se nos cabelos do homem (Figueiredo, 2010, p. 119).

Mais que isso, quando se sugere a saciedade dos representantes de ambas as classes - os jovens e classe média e os jovens moradores de rua que compartilham do mesmo prazer -, demonstra a perda da fala pelo pai de Rosane e por ela mesma perante a TV ou informa acerca do grau de identificação que alcançam os personagens desses produtos de massa, a ponto de se tornarem referência para nomear. O quadro do jogo aponta o efeito catártico-coercitivo que exercem esses elementos, o que torna o vaticínio do juiz, que na obra se configura como uma provocação sem efeito, um temor sem razão.

\section{Conclusão: a vida à espreita}

Em que medida Passageiro do fim do dia pode ser tomada como uma narrativa de memórias? Só se considerarmos assim toda obra em que a memória está presente, inclusive aquelas em que a forma do narrador não é homo nem intradiegética, mas exerce a função de costurar a sua irradiação. Vimos que nesse romance essa costura é uma estratégia discursiva. $\mathrm{O}$ narrador distancia-se em graus das memórias de Pedro, utilizando a modulação do discurso, que alterna do indireto para o indireto livre, o que tem força de proposição, como elemento significativo. Esse é um dado poderoso e não deve ser negligenciado, sob pena de se perder a integridade do romance. Não se trata, portanto, de obra confessional.

Tendo em mente a forma que adquire a instância da enunciação, é arriscado categorizá-la como obra resultante do fluxo de consciência, tal qual ele surge como recurso moderno. A dispersão dos quadros que nascem por associações de Pedro, associações cujo fio da meada ele ignora, não acentuam a dispersão em si mesma, mas provocam a busca pela razão de ser de sua forma específica, e o ritmo dessas associações é conduzido também por forças externas à ética subjetiva das suas memórias.

Acompanhamos o refinamento da montagem: à medida que Pedro se abandona às memórias e reflexões, as associações que realiza levam-nos de um quadro a outro. As dúvidas que o protagonista apresenta e repõe, sua angústia atrás das respostas que ele procura 
através da observação detalhada, só lhe entregam sugestões, insinuações de que existe um fio arregimentador que ele não captura, mas que está na matéria e vive para além dele mesmo. Mas o narrador, mesmo quando marcadamente distante e autônomo das memórias de Pedro, também nada esclarece diretamente, apenas insinua, através de recursos como a fina ironia do indireto livre em dadas passagens, a relativização da obsessão descritiva, a repetição sistemática de termos etc. Esse fio, essa razão da emergência das forças de determinadas imagens entrelaçadas é esclarecida no romance através da discreta retificação de dados, do atrito no espaço da quebra da enunciação, da retomada de informações ou memórias sob outras perspectivas que esclarecem outras faces de um mesmo objeto.

A leitura do romance nessa chave parece indicar que a concretude espacial comparece na forma como Sabino (2015) os lê, como índices de algo mais concreto do que aquilo que se enxerga, nesse caso, muito menos do que apenas provocadores da formalização da memória afetiva de Pedro por si só, como sugerem Santos e Fux (2013) e Patrocínio (2013). A subjetividade das associações não basta ao romance, pois a obra não se contenta em constatar, não se detém em mostrar os efeitos da devastação que provoca no sujeito. Há uma procura pelas suas razões, que são objetivas e afetam o coletivo. Esse dado objetivo escondido, como analisado, é estrategicamente disperso pela lógica que preside a montagem de Passageiro do fim do dia.

Patrocínio (2013) aponta a ironia e desmistificação propostas através das referências ao naturalismo e, nessa direção, avança em relação à mera verificação de que elas levam à construção de metáforas de opressão e brutalidade. Contudo, o que é desmitificado lhe escapa. O romance não autoriza a concluirmos que a crítica ao cientificismo darwiniano, articulado à crítica aos padrões de representação naturalista, está a serviço do atestamento do fracasso da própria representação da realidade e sua dinâmica material. Existe uma depreciação, tal qual a análise nos mostra, do componente determinista da teoria e da sua apropriação para justificação da brutalidade em si, o seu rebaixamento.

Passageiro do fim do dia trata-se, em suma, de um livro cuja composição é um elemento de significado, como aponta o estudo de Lota (2013). Mas o que significa? Rubens Figueiredo indica: 
Acredito que um romance, um conto ou um poema tem muito a ganhar se o autor partir do pressuposto de que a obra pode contribuir para o conhecimento do mundo, da vida. Isso significa que aquilo, romance, conto ou poema, não é uma coisa ornamental nem apenas uma manifestação hermética de uma subjetividade impenetrável (Figueiredo, 2012, p. 8).

É o próprio Figueiredo quem assinala a preocupação com o teor de verdade da sua obra, no sentido de ela procurar ser a enunciação de algo além um recorte, uma estilização ou a plasmação de uma ética impenetrável. Sua preocupação com a forma da obra é uma preocupação com esse valor, com o encontro de uma forma que esclareça o que a obra se propõe como agente de conhecimento.

A gente escreve para contribuir para o conhecimento. É isso que eu quero dizer. Mas conhecer o quê? Qualquer coisa. As coisas não existem isoladas. Você pode dizer: ah, eu quero contribuir para o conhecimento da subjetividade. Mas subjetividade não existe fechada em si mesmo, ela está submetida a fatores comuns. Aí, então, tem a discussão: mas se você parte dessa ideia que é uma questão de conhecimento, muda muito. Não estou falando que a literatura não é política. A literatura é política. O conteúdo da uma obra vai ser formado por fatores do seu tempo, fatores objetivos, concretos. Claro que se você tiver a consciência disso, alcança outros resultados: consegue conduzir aquilo de uma maneira mais consciente. Mas se você não tiver, vai falar com uma voz que não é a sua (Figueiredo, 2012, p. 9).

No trecho acima, Figueiredo reforça a necessidade de que uma obra apresente uma proposição, um teor de verdade, e ratifica nossas conclusões acerca da não centralidade da subjetividade na fatura de seu romance. Ainda, o autor aponta a relação entre conteúdo e forma como algo que evidencia o caráter político da literatura: à medida que se conhecem os determinantes do seu conteúdo, buscar-se-ão formas que funcionem ao seu esclarecimento:

Aliás, muitas vezes nós dizemos o seguinte: um autor é contido, tem uma linguagem contida. Encara-se a afirmação como um elogio. Mas pense bem: o que há de bom nisso? $\mathrm{O}$ fato do sujeito medir as palavras que é bom? É uma técnica de linguagem? É uma escolha de palavras que torna aquilo bom? 
Não. Minha convicção, hoje, é a seguinte: o contido será bom dependendo do teor daquilo que é contido, daquilo que está contido, daquilo que não aparece [...]. Bom, não sei quando percebi o que acontecia dentro dos ônibus, nas viagens que eu fazia, na ida e na volta do trabalho, mas esse sentido, essa experiência, está presente no meu romance Passageiro do fim do dia. Essa atmosfera está presente de forma subjacente. Eu queria que a tensão da narração do meu livro tivesse como conteúdo essa experiência e pressão subjacentes. É tudo um rolo, não é? (Figueiredo, 2012, p. 9).

Em entrevista concedida em 2011, Figueiredo trata especificamente de como esses imperativos que coordenam sua atividade de escritor aparecem em Passageiro do fim do dia. Figueiredo reconhece que um enredo tradicional não contribuiria para o esclarecimento da ordem problemas que a obra quer iluminar, uma vez que o enredo tradicional resguarda e legitima determinadas relações sociais, tão sedimentadas que sequer conseguimos percebêlas como tais dentro do romance:

Algumas preocupações não eram novas. Por exemplo, eu não queria um livro em que houvesse um enredo propriamente [...]. O entrecho, o enredo tinha um conflito, uma crise e um desfecho, e pronto. Acho que isso que eu encontrei há pouco tempo lendo Tolstói traduz o seguinte: há formatos nas obras artísticas que se tornaram um padrão já quase assimilado à própria ideia de romance ou de obra arte, mas que, na verdade, são determinações da época, determinações de relações sociais. É como se aquela ordem social estivesse falando por meio dessa composição. Ou que, nessa composição, aquela ordem social estivesse mais resguardada. Talvez seja isso (Figueiredo, 2011, p. 193).

A dispersão da matéria, o dado escondido e reposto pela montagem, são mesmo necessidades de sua obra. $\mathrm{O}$ intuito de tratar das questões sociais caras a Figueiredo levou-o a construir um personagem cuja dispersão é o polo irradiador da matéria e acentua o grau de obnubilidade de sua visão. Se a intenção do autor era acentuar a forma como a desigualdade social se camufla e naturaliza, Pedro é o protagonista ideal para tal. Disperso, ele retém o fragmento e é incapaz de acessar o processo que torna algo 
orquestrado como natural. Fica claro, como nossa análise procurou mostrar, que só à montagem é possível recorrer para que tal processo se descortine, sendo ele um processamento mesmo, inscrito na malha do romance, o expediente de pôr e repor objetos, fatos, personagens, dispô-los pelo romance e insinuar suas relações uns com os outros:

Eu tinha também a preocupação de encontrar um caminho para investigar a maneira como nós tratamos a desigualdade, as dificuldades que temos de perceber que certas coisas são constituídas por processos, não estão dadas de antemão, como algo natural - para mim, a dificuldade de perceber isso era uma coisa que valia a pena ser investigada na obra de ficção, é o tipo de assunto que parece produtivo, fecundo. Eu queria também um livro que tivesse alguma ramificação, alguma via aberta para permitir uma compreensão histórica mais abrangente. Porque aquelas questões miúdas, aqueles processos insignificantes do cotidiano, estão ali para traduzir os mecanismos de opressão - é o que eles são, na verdade. Para que eles pudessem ser manifestados assim, tinha que haver um horizonte histórico de algum alcance, de alguma abrangência. Procurei alguns acessos para isso. Imaginei compor um quadro que fosse revelador de processos que não são visíveis à primeira vista. Ao contrário, são processos que querem se esconder, é intrínseco a eles se manterem ocultos (Figueiredo, 2011, p. 194).

A pretensão holística de Passageiro do fim do dia leva à verdade histórica que o livro quer enunciar. Todas as referências ao trabalho, à opressão, ao modo em que surge a crítica ao evolucionismo, à barbárie, à sedução da violência, à padronização da vida e do homem inserido numa ordem "global", a alienação pelo entretenimento de massa, às assimetrias de gênero, o fetiche da mercadoria etc., tudo isso pretende mostrar como sua repetição e estilização servem para camuflar a ordem injusta da prevalência do capital, através dos recursos de montagem acima descritos, cuja função é desencantar o conteúdo como forma (Marx e Engels, 2001).

Certo restabelecimento da ordem, suspensão da tensão e aplainamento na atmosfera vão se processando. Pedro é, e ele se dá conta disso, alguém diferente dos moradores do Tirol, o que constitui é uma limitação sua, dada por condições sociais, de certa forma imutável. Esse desfecho reincide sobre a impossibilidade de identificação, de esclarecimento, e pode reforçar uma conclusão 
negativa em resposta à resolução do problema central formalizado no romance. Mas pode ser lido em outra chave, a de que talvez, para Pedro, haja uma saída: a identidade. O desfecho do romance sugeriria, assim, a saída pelo ajustamento, processado ao longo da narrativa.

É Figueiredo quem afirma:

A indignação a que você se refere, eu acho que é resultado de um processo, de uma insatisfação coletiva. À medida que o sujeito começa a ver as pessoas como iguais a ele, e não como bestas ou aranhas, aí ele começa a ficar indignado. Mas ele tem que romper essa barreira, tem que passar a ver os outros como gente, como a um igual. Essa é uma das grandes barreiras que existem no nosso cotidiano. Eu achei que esse tipo de livro poderia investigar isso, questionar isso. Não dar uma resposta, mas proporcionar uma experiência em que a gente possa questionar isso (2011, p. 203).

Uma proposição um tanto romântica, se pensarmos que, por fim, em sonho, Pedro reconhece seus limites à identificação, insinuando compreender sua natureza de classe, mas, apesar disso, decide seguir desesperadamente para o Tirol, junto de seus companheiros de viagem, obstinadamente ao encontro de Rosane, o que configura sua redenção. Não tanto, contudo, se tivermos em mente que, tendo sido essa decisão tomada no plano onírico, "Pedro ouviu o motorista responder que, se o trânsito não piorasse nem tivessem de desviar o itinerário, faltavam só uns quinze minutos para chegar" (Figueiredo, 2010, p. 197). Quinze minutos parece agora bem pouco, se considerada a extensão da viagem. E isso Pedro ouviu já desperto.

\section{Referências}

FIGUEIREDO, Rubens (2006). Contos de Pedro. São Paulo: Companhia das Letras. FIGUEIREDO, Rubens (2010). Passageiro do fim do dia. São Paulo: Companhia das Letras.

FIGUEIREDO, Rubens (2011). Entrevista. Terceira Margem, Rio de Janeiro, ano 15, n. 24, p. 194-207, jan./jul.

FIGUEIREDO, Rubens (2012). Um escritor na Biblioteca: Rubens Figueiredo. Cândido: Jornal da Biblioteca Pública do Paraná, Curitiba, n. 15, p. 4-9, out. 
LOTA, Roberto de Andrade (2013). Gritos e ressonâncias do secreto: a poética narrativa de Rubens Figueiredo. Dissertação (Mestrado em Letras Vernáculas) - Universidade Federal do Rio de Janeiro, Rio de Janeiro.

MARX, Karl; ENGELS, Friedrich (2001). A ideologia alemã. São Paulo: Martins Fontes.

MARX, Karl; ENGELS, Friedrich (2011). O manifesto comunista. São Paulo: Hedra.

PATROCÍNIO, Paulo Roberto Tonani do (2013a). Ler a cidade pela janela de um ônibus. Brasil/Brazil, Providence, ano 26, n. 48.

PATROCÍNIO, Paulo Roberto Tonani do (2013b). Passageiro do fim do dia, de Rubens Figueiredo: um olhar sobre o naturalismo. In: CHIARELLI, Stephania; DEALTRY, Giovanna; VIDAL, Paloma. O futuro pelo retrovisor: inquietudes da literatura brasileira contemporânea. Rio de Janeiro: Rocco.

PATROCÍNIO, Paulo Roberto Tonani do (2013c). Os (não) adaptados: a experiência urbana na obra de Rubens Figueiredo. Revista Sapientia, Roma, ano 32, n. 145.

SABINO, Thais de Carvalho (2014). Passageiro do fim de dia, de Rubens Figueiredo: cidade fragmentada. In: SIMPÓSIO INTERNACIONAL SOBRE LITERATURA BRASILEIRA CONTEMPORÂNEA, 6., 2 a 5 nov. 2014, Universidade de Brasília. Anais... Brasília: GELBC.

SANTOS, Darlan; Fux, Jacques (2013). A dramaticidade urbana em "Passageiro do fim do dia", de Rubens Figueiredo. Fronteira Z, São Paulo, n. 11.

TIRLONI, Larissa Paula (2012). Memória e espaço em "Passageiro do fim do dia". In: INLETRAS: SEMINÁRIO INTERNACIONAL DE LETRAS, 12., 9 a 22 jun. 2012, Centro Universitário Franciscano. Anais... Santa Maria: Unifra.

Recebido em 25 de julho de 2017.

Aprovado em 21 de janeiro de 2018.

\section{resumo/abstract/resumen}

\section{A violência insuspeita da sociedade de classes no trâmite da enunciação em Passageiro do fim do dia}

Danieli Christovão Balbi

Em Passageiro do fim do dia, a forma como se estabelece o trâmite entre sujeito do enunciado e sujeito da enunciação põe em evidência as estratégias de que 
se lança mão para a apreensão do dado objetivo do "real", cuja inapreensibilidade se torna, na fatura do romance de Rubens Figueiredo, índice que costura materialidades e sentidos, concretudes e simbologias sutis para o desvelamento da lógica das violências e de como elas se tornam cotidianas, banais e necessárias à reprodução de um modo de viver, se relacionar e sentir imposto pela dinâmica da sociedade de classes.

Palavras-chave: Rubens Figueiredo, Passageiro do fim do dia, enunciação, realismo.

\section{The unsuspected violence of the class society in the process of enunciation in Passageiro do fim do dia}

Danieli Christovão Balbi

In Passageiro do fim do dia, the way in which the process is established between subject of the enunciate and subject of enunciation highlights the strategies that are used to apprehend the objective data of the "real", whose inapreensibility becomes, in the invoice from the novel by Rubens Figueiredo, an index that stitches together materialities and subtle meanings, concretions and symbologies for the unveiling of the logic of violence and how they become everyday, banal and necessary to the reproduction of a way of living, to relate and to feel imposed by the dynamics of class society.

Keywords: Rubens Figueiredo, Passageiro do fim do dia, enunciation, realism.

\section{La violencia insospechada de la sociedad de clases en el trámite de la enunciación en Passageiro do fim do dia}

Danieli Christovão Balbi

En Passageiro do fim do dia, la forma como se establece el trámite entre sujeto del enunciado y sujeto de la enunciación pone en evidencia las estrategias de que se lanza mano para la aprehensión del dato objetivo del "real", cuya inapreensibilidad se vuelve, en la factura de la novela de Rubens Figueiredo, índice que costura materialidades y sentidos, concreciones y simbologías sutiles para el descortino de la lógica de las violencias y de cómo se vuelven cotidianas, banales y necesarias para la reproducción de un modo de vivir, relacionarse y sentir impuesto por la dinámica de la sociedad de clases.

Palabras clave: Rubens Figueiredo, Passageiro do fim do dia, enunciación, realismo. 